\title{
Comparison of oral microbiota in tumor and non-tumor tissues of patients with oral squamous cell carcinoma
}

\author{
Smruti Pushalkar ${ }^{1}$, Xiaojie Ji ${ }^{1,2}$, Yihong Li ${ }^{1}$, Cherry Estilo ${ }^{3}$, Ramanathan Yegnanarayana ${ }^{4}$, Bhuvanesh Singh ${ }^{4}$, \\ Xin $\mathrm{Li}^{1}$ and Deepak Saxena ${ }^{1 *}$
}

\begin{abstract}
Background: Bacterial infections have been linked to malignancies due to their ability to induce chronic inflammation. We investigated the association of oral bacteria in oral squamous cell carcinoma (OSCC/tumor) tissues and compared with adjacent non-tumor mucosa sampled $5 \mathrm{~cm}$ distant from the same patient $(n=10)$. By using culture-independent 165 rRNA approaches, denaturing gradient gel electrophoresis (DGGE) and cloning and sequencing, we assessed the total bacterial diversity in these clinical samples.

Results: DGGE fingerprints showed variations in the band intensity profiles within non-tumor and tumor tissues of the same patient and among the two groups. The clonal analysis indicated that from a total of 1200 sequences characterized, 80 bacterial species/phylotypes were detected representing six phyla, Firmicutes, Bacteroidetes, Proteobacteria, Fusobacteria, Actinobacteria and uncultivated TM7 in non-tumor and tumor libraries. In combined library, 12 classes, 16 order, 26 families and 40 genera were observed. Bacterial species, Streptococcus sp. oral taxon 058, Peptostreptococcus stomatis, Streptococcus salivarius, Streptococcus gordonii, Gemella haemolysans, Gemella morbillorum, Johnsonella ignava and Streptococcus parasanguinis I were highly associated with tumor site where as Granulicatella adiacens was prevalent at non-tumor site. Streptococcus intermedius was present in $70 \%$ of both non-tumor and tumor sites.

Conclusions: The underlying changes in the bacterial diversity in the oral mucosal tissues from non-tumor and tumor sites of OSCC subjects indicated a shift in bacterial colonization. These most prevalent or unique bacterial species/phylotypes present in tumor tissues may be associated with OSCC and needs to be further investigated with a larger sample size.
\end{abstract}

Keywords: Microbial diversity, Oral squamous cell carcinoma, Microbiota, Tumor, Non-tumor

\section{Background}

Oral cancer is one of the ten most prevalent cancers in the world with more than $90 \%$ of mouth neoplasms being squamous cell carcinoma that has its origin from the oral mucosa [1-3]. During the year 2011, in United States, approximately, 39,400 new cases and 7,900 deaths were estimated attributing to cancer of oral cavity and pharynx [4]. Five year survival rates for persons with this medical condition are currently only $60.9 \%$ [4]. The early

\footnotetext{
*Correspondence: ds100@nyu.edu

'Department of Basic Sciences and Craniofacial Biology, New York University College of Dentistry, 345 E, 24th Street, Room 921B, New York, NY 10010, USA

Full list of author information is available at the end of the article
}

detection of oral cancer at initial stages is critical and requires less radical treatment for patient's survival and improving quality of life. The pathogenesis of OSCC is attributed mainly to smoking, heavy alcohol consumption and smokeless tobacco products [5-7]. Other possible risk factors include viral infections [8,9], infection with Candida species [10], periodontitis [11,12], poor oral hygiene [13], poor dental status [14] and chronic bacterial infections and inflammation [5,6,15-17].

The association of bacterial infection and cancer is classically represented by Helicobacter pylori and its involvement in gastric adenocarcinoma and mucosa associated lymphoid tissue (MALT) lymphoma [18]. Some studies suggests possible link between Salmonella typhi

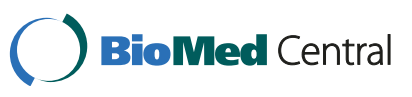


and gall bladder cancer, Streptococcus bovis and colon cancer, Chlamydophila pneumoniae and lung cancer, Bartonella species and vascular tumor formation, Propionibacterium acnes and prostate cancer and Escherichia coli in inflammatory bowel disease with increased risk of colon cancer $[15,19,20]$. These findings were confirmed by using several animal (mice) models for Helicobacter hepaticus associated with hepatocellular carcinoma [21], colon cancer [22] and cancer in mammary glands [23]. There is growing evidence that bacterial infection is causally related to carcinogenesis.

Several mechanisms for possible bacterial association in carcinogenesis may include chronic infection by evasion of immune system and immune suppression [24], or induction of chronic inflammation [25], or direct or indirect interference with eukaryotic cell cycle and signaling pathways $[8,15]$, or via metabolism of potential carcinogenic substances [7]. The host cells are susceptible to microbial endotoxins (lipopolysaccharides), enzymes (proteases, collagenases, fibrinolysin and phospholipase) and their metabolic by-products (hydrogen sulfide, ammonia and fatty acids) and may directly induce mutations in tumor suppressor genes and proto-oncogenes or alter signaling pathways that affect cell proliferation and/ or survival of epithelial cells [8,15,24]. Microorganisms and their products activate neutrophils, macrophages, monocytes, lymphocytes, fibroblasts and epithelial cells to generate reactive species (hydrogen peroxide and oxygen radicals), reactive nitrogen species (nitric oxides), reactive lipids and metabolites (malondialdehyde and 4-hydroxy-2 -nonenal) and matrix metalloproteases. These compounds can induce DNA damage in epithelial cells [20] and directly affect tumor growth by activating tumor cell toll-like receptors (TLR) that eventually leads to nuclear translocation of the transcription factor NF-kB and cytokines production [26,27]. These cytokines are produced in dysregulated fashion and have roles in cell growth, invasion and interruption of tumor suppression, immune status and even survival [28]. It is unclear whether these mediators are critical for the development and/or growth of tumors and/or whether they constitute a permissive environment for the progression of malignancies [29]. Elevated levels of certain proinflammatory, proangiogenic NF-kB dependent cytokines TNF- $\alpha$, IL-1, IL-6, IL-8, GM-CSF and VEGF were observed in serum, saliva, and tissue specimens of patients with oral cancer [30,31].

The oral cavity harbors diversified microflora with more than 750 distinct bacterial taxa [14] that colonize host tissues and co-aggregate with one another [32]. Any loss in integrity of oral epithelial barrier exposes the underlying tissues to various aerobic and anaerobic microflora of oral cavity [33]. Hence, the local and systemic polymicrobial mucosal infections may be a result of invading potentially pathogenic microorganism of extra-oral origin or a shift within the normal commensal microflora taken up by opportunistic microflora in immuno-compromised individuals [33].

Previous studies on oral microbiota of patients with and without OSCC using culture-dependent [10,33-36] and culture-independent [37-40] techniques indicated bacterial community profiles to be highly correlated at phylum level but diverse at genus level. Hooper et al. $[34,38]$ observed that most of the taxa in non-tumor and tumor tissues were known members of oral cavity and majority of those in tumor tissue were saccharolytic and aciduric species. Our studies on bacterial diversity in saliva samples by 454 pyrosequencing revealed 244 bacterial OTUs exclusive to OSCC patients $(n=3)$ as compared to non-OSCC controls $(n=2)$ [40]. To establish the role of bacteria in OSCC, it is important to determine the differences in the colonization of oral bacteria in non-tumor and tumor tissues. We hypothesized that any differences in bacterial profile at tumor sites in contrast to non-tumor sites may indicate its involvement in tumor pathogenesis.

We used 16S rRNA based two culture-independent methods, denaturing gradient gel electrophoresis and sequencing to elucidate the total oral microbiota in nontumor and tumor tissues of OSCC patients. This may facilitate to identify the microbial transition in nontumor and tumor tissues and understand better the association of bacterial colonization in OSCC.

\section{Methods}

\section{Subject selection and sampling procedure}

Twenty oral tissue samples, 10 each from non-tumor and tumor sites of 10 patients with squamous cell carcinoma of oral tongue and floor of the mouth, median age 59 years (53\% male and $47 \%$ female) were obtained from Memorial Sloan-Kettering Cancer Center (MSKCC) Tissue Bank, refer Estilo et al. and Singh et al. [41-43] for clinical details. The subjects had a history of smoking and drinking and were not on antibiotics for a month before sampling. The study was approved by institutional review boards at MSKCC and NYU School of Medicine and written informed consent was obtained from all participants involved in this study. The tissues were collected following guidelines established by Institutional Review Board at MSKCC and tumors were identified according to tumor-node-metastasis classification by American Joint Committee on Cancer/Union International Cancer Center.

For this study, to have a homogenous sample population and to control the effect of confounding factors on bacterial colonization, we used non-tumor tissue from upper aerodigestive tract as a control, resected $5 \mathrm{~cm}$ distant from the tumor area or contralateral side of the same OSCC patient and confirmed histologically as 
normal mucosae [42]. The tissue samples were processed to include all bacteria (on the surface and within the tissue) to detect the total bacterial diversity in oral mucosa. The samples were procured and stored at $-80^{\circ} \mathrm{C}$ till further analysis.

\section{DNA extraction from tissue samples}

Tissue specimens were pretreated as mentioned earlier by Ji et al. [44]. Briefly, the tissues were suspended in $500 \mu \mathrm{L}$ of sterile phosphate-buffered saline (PBS), vortexed for 30 seconds and sonicated for 5 and 10 seconds respectively. Proteinase $\mathrm{K}(2.5 \mu \mathrm{g} / \mathrm{mL})$ was added for digestion and incubated overnight at $55^{\circ} \mathrm{C}$, if required, homogenized with sterile disposable pestle and vortexed. The bacterial genomic DNA was extracted by modified Epicentre protocol (Epicentre Biotechnologies, Madison, WI) and purified with phenol-chloroform extraction [45]. Samples were analyzed qualitatively and quantitatively by NanoDrop ND 1000 spectrophotometer (NanoDrop Technologies Inc., Wilmington, DE). All samples were stored at $-20^{\circ} \mathrm{C}$ till further analysis. For PCR assays, the DNA concentration was adjusted to $20 \mathrm{ng} / \mu \mathrm{L}$.

\section{S rDNA amplification}

The 16S rDNA samples were amplified as described earlier [44] using universal primer pair $8 \mathrm{~F}$ and $1492 \mathrm{R}$ [46-48] for cloning. PCR reactions were run at $95^{\circ} \mathrm{C}$ for $5 \mathrm{~min}$, followed by 30 cycles of denaturation at $95^{\circ} \mathrm{C}$ for $1 \mathrm{~min}$, annealing at $52^{\circ} \mathrm{C}$ for $1 \mathrm{~min}$, and elongation at $72^{\circ} \mathrm{C}$ for $1 \mathrm{~min}$ with final elongation at $72^{\circ} \mathrm{C}$ for $5 \mathrm{~min}$. The nested PCR was performed targeting V4-V5 hypervariable region with another set of eubacterial primers, prbac1 and prbac2 [49] with 40-nucleotide GC clamp [50] added to 5' end of prbac1 for DGGE assay. The conditions of nested PCR were $3 \mathrm{~min}$ preheating at $94^{\circ} \mathrm{C}, 35$ cycles each at $94^{\circ} \mathrm{C}$ (30 seconds), $63^{\circ} \mathrm{C}$ (40 seconds), and $72^{\circ} \mathrm{C}(1 \mathrm{~min})$, final extension at $72^{\circ} \mathrm{C}$ for $7 \mathrm{~min}$. For both PCR assays, the reaction system was $50 \mu \mathrm{L}$ comprising $1 \mu \mathrm{L}$ DNA template, $5 \mathrm{U}$ Taq DNA polymerase (Invitrogen, Carlsbad, CA), $5 \mu \mathrm{L}$ 10x PCR buffer, $1.5 \mu \mathrm{L} \quad \mathrm{MgCl}_{2}$ (50 mM), $4 \mu \mathrm{L}$ dNTP mixture $(2.5 \mathrm{mM}$ each) and $50 \mathrm{pmol}$ of each primer.

\section{DGGE assay}

PCR products from nested PCR were analyzed for sequence polymorphism on $40 \%$ to $60 \%$ linear DNA denaturing gradient polyacrylamide gel, $8.0 \% \mathrm{w} / \mathrm{v} .30 \mu \mathrm{L}$ of each were loaded on DGGE gel with standard speciesspecific DGGE reference markers [40,51] resolved by DCode system (Bio-Rad, Hercules, CA). The gels were run for $16 \mathrm{hr}$ at $58^{\circ} \mathrm{C}$ and $60 \mathrm{~V}$ in $1 \mathrm{x}$ Tris-acetate-EDTA (TAE) buffer, pH 8.5 and stained with ethidium bromide solution $(0.5 \mu \mathrm{g} / \mathrm{mL})$ for $15 \mathrm{~min}$. The images were digitally documented using Alpha Imager 3300 system (Alpha Innotech Corporation, San Leandro, CA).

Cluster and statistical analyses of DGGE microbial profiles DGGE gel pattern of amplicons were analyzed with the aid of Fingerprinting II Informatix Software (Bio-Rad) and interpreted statistically [52]. The gels were normalized with DGGE standard markers and background subtracted using mathematical algorithms based on spectral analysis of overall densitometric curves. The similarity among samples was calculated by Dice coefficient. Dendrogram was configured from average matrix by Ward analysis. The variations in microbial profiles of nontumor and tumor tissues were assessed by comparing inter- and intra- groups DGGE profiles of PCR amplified segments. Differences were examined for statistical significance using Mann-Whitney $U$ test and Chi-square test. Statistical analysis was performed using SPSS software v. 17.0 (SPSS inc., Chicago, IL).

\section{Cloning and sequencing}

PCR amplicons were ligated to pCR4-TOPO vector and transformed into $E$. coli TOP10 cells using TOPO-TA cloning kit according to manufacturer's instructions (Invitrogen). From each sample, about 95-96 clones were picked and a total of 1914 clones were sequenced unidirectional (Beckman Coulter Genomics, Beverly, MA) using BigDye Terminator v3.1 and 806r sequencing primer and analyzed on ABI PRISM 3730xl coupled with Agencourt CleanSEQ dye terminator removal for generation of long high quality Sanger sequencing reads. About 1200 sequences with Phred 20 and average read length of 700 bases were trimmed by removing vector sequences and adjusted for quality values. The majority of single sequence read length was between 350-900 bases. All the trimmed sequences were verified manually for vector sequences using EMBOSS pairwise alignment algorithms [53].

\section{Phylogenetic analysis of sequences in group specific libraries}

Sequences were aligned with Greengenes Nast aligner (http://greengenes.lbl.gov) [54] and then checked for chimeras on greengenes chimera check program supported by Bellerophon [54,55]. About $0.7 \%$ sequences were chimeric and eliminated from analysis. The sequences with 350 to 900 bases were analyzed against 16S rRNA reference sequences of Human Oral Microbiome Database (HOMD, version 10.1) [56,57]. Sequence identification requires a single read of approximately 350 to 500 bases [58]. The threshold assigned for BLAST identification of partial sequences was $\geq 98 \%$ similarity for species/ phylotypes. Majority of sequences could be identified to species/phylotype level. The sequences with $<98 \%$ 
identity were characterized only till genus level and considered unclassified sequences at species level. Non-tumor and tumor libraries were constructed from clonal analysis. These sequences were also analyzed using Ribosomal Database Project (RDP, Release 10) [59]. The relative distribution of abundance for phylogenetic groups in two different libraries was compared by chisquare test. The intra- (within) and inter- (between) groups bacterial species/phylotypes in $16 \mathrm{~S}$ clonal libraries were evaluated. In analysis, for representation of bacterial taxa, the term, species refers to named cultivated species and unnamed cultivated taxon and phylotypes refers to non-cultivable or yet- uncultured species.

\section{Diversity and richness estimation of group specific libraries}

Richness estimator, Chao1 was determined by ESTIMATES v. 7 [60] and rarefaction curves, rank abundance and diversity indices performed in PAST v. 1.89 [61]. The species rarefaction of the entire dataset was computed by individual rarefaction method. The percentage of coverage was calculated by Good's method using equation $(1-n / N) \times 100$, where $n$ is number of singletons represented by one clone in the library and $\mathrm{N}$ is total number of sequences in the sample library [62]. The diversity of each sampled sequence set was estimated by using Shannon $\left(H^{\prime}\right)$ and Simpson $(1-D)$ indices within PAST application. The Shannon index of evenness was calculated with the formula $E=\mathrm{e}^{\wedge} \mathrm{H} / \mathrm{S}$, where $\mathrm{H}$ is Shannon diversity index and $\mathrm{S}$ is number of taxa (species/phylotypes) in that group.

\section{Results}

In this study, DGGE was used as a method for preliminary and rapid assessment of bacterial diversity in tumor and non-tumor tissues. DGGE gel profiles of non-tumor and tumor samples $(n=20)$ were analyzed after normalization of gels with species-specific markers (Figure 1). In total, 68 and 64 bands were distinct to non-tumor and tumor groups respectively of which 8 bands were exclusive to non-tumor samples while 4 bands exclusive to tumor group. Each band may correspond to one or more bacterial species. The band distribution of bacterial population in individual samples ranged from 20 to 26 (mean $22.40 \pm 1.71 \mathrm{SD}$ ) in non-tumor where as 15 to 26 bands (mean 20.60 $\pm 3.10 \mathrm{SD}$ ) in tumor groups. The MannWhitney $U$ test to compare the Shannon-Weaver indexes of diversity $\left(\mathrm{H}^{\prime}\right)$ in non-tumor and tumor samples showed no significant differences ( $p>0.05$, two-tailed) in oral microbiota between two sample groups. The inter- group similarities were found to be $40 \%$ to $80 \%$ by cluster analysis (Figure 2). Most of the clinically distinct samples (non-tumor and tumor) from the same patients clustered together with exception of one sample (184_N and 184_T) as seen in their intensity profiles.

Similarity index (SI) was calculated based on the total number of high and low intensity bands per lane and position of band migration reflecting number of bands the two lanes have in common. The values signify similarities in bacterial composition between non-tumor and tumor groups (Table 1). The tumor samples (intragroup), 1457_T and 527_T showed total dissimilarity in their profiles despite sharing the same group. The band similarity correlation was highest in non-tumor and tumor tissue samples (inter- group), 142_N/142_T (77.27\%) and 146_N/146_T (71.43\%) from the same patient indicating that most of the microbiota were common at both the sites but there were changes in the bacterial composition. Chi-square test indicated significant differences in intra- and inter- groups bacterial profiles $\left(X^{2}=10.76, p=0.005\right)$.

The alterations in DGGE fingerprinting profiles indicated that different bacteria colonize the two oral sites, non-tumor and tumor of OSCC patients. This prompted us to conduct cloning and sequencing studies using $16 \mathrm{~S}$ rDNA amplification to identify microbiotal populations at these sites. The clonal libraries with clinical distinctions were constructed with approximately 1200 high quality sequences from the rDNA inserts of non-tumor and tumor tissues. About $276(\sim 22.9 \%)$ sequences with $<350$ bases and 14 chimeric sequences (1.2\%) were eliminated from analysis. The filtered 914 (75.9\%) sequences of 350-900 bases from combined (non-tumor and tumor) library were characterized, of which 107 sequences (8.9\%) with $<98 \%$ sequence identity accounted for genus level classification and were uncharacterized at species level. The remaining 807 (67\%) sequences having $>98 \%$ sequence identity to $16 \mathrm{~S}$ rRNA reference sequences in HOMD were classified to species level.

Figure 3a shows the \% distribution of phyla at tumor and non-tumor sites of the patient population. The filtered 914 sequences matched 6 bacterial phyla, in their degree of dominance, Firmicutes, Bacteroidetes, Proteobacteria, Fusobacteria, Actinobacteria and uncultivated TM7 were detected in both non-tumor and tumor libraries (Figure 3b). The frequency of phylum Firmicutes was major in tumor tissues (85\%) as compared to non-tumor tissues $(74.6 \%)$ whereas the frequency of other phyla was higher in non-tumor library. The composition of bacterial communities at tumor site was different in comparison to the non-tumor site in most of the patients (Figure 4a). In combined library, 12 classes, 16 order, 26 families and 40 genera were observed and their relative distribution in individual non-tumor and tumor library is demonstrated in (see Additional file 1: Figure S1, Additional file 2: Figure S2, Additional file 3: Figure S3) and Figure 4b 


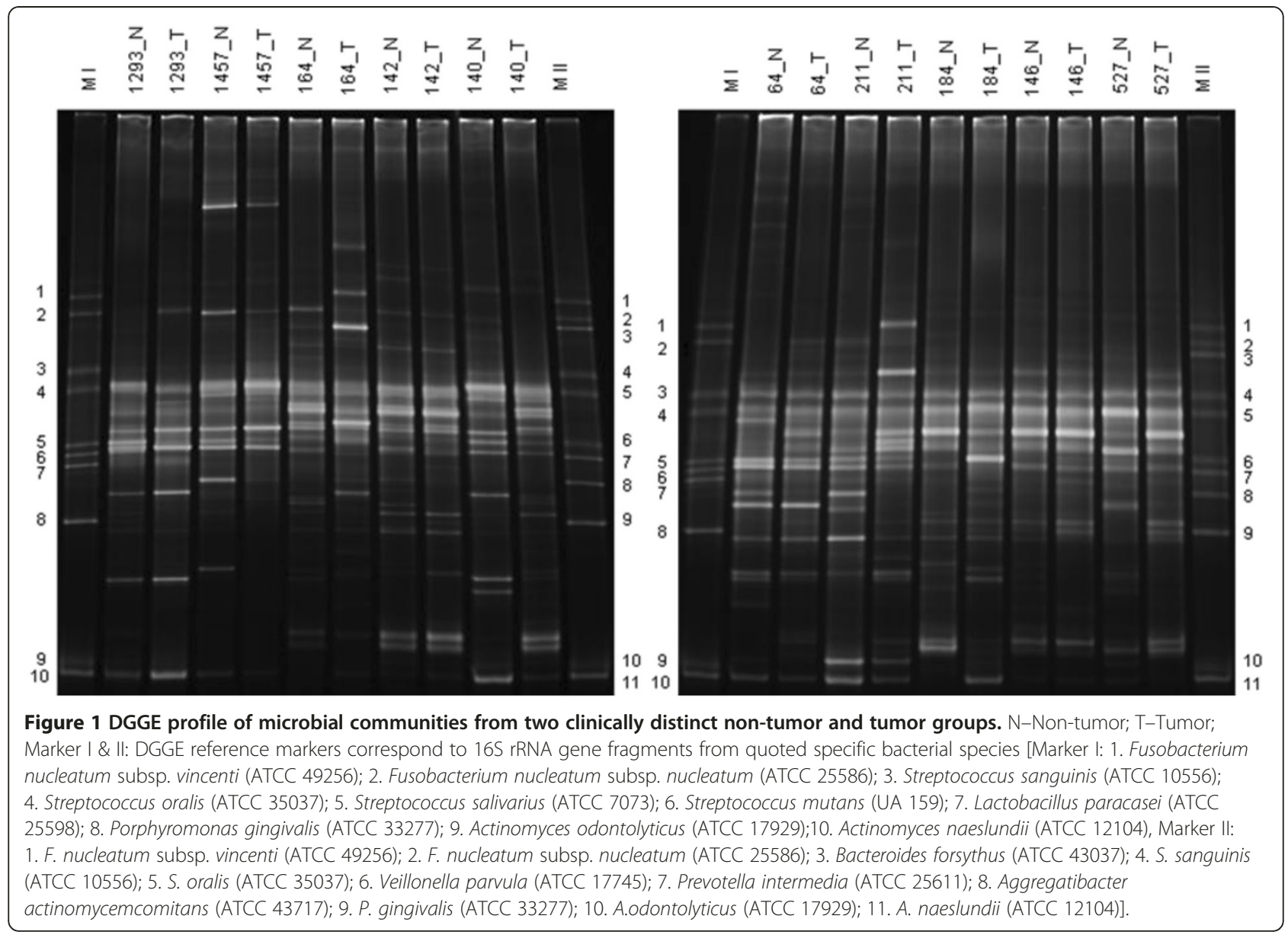

respectively. The most prevalent classes were Bacilli (66.6\%) that includes order, Lactobacillales (54.8\%) and Bacillales (11.8\%) in tumor library while Clostridia (20.5\%) and Bacteroides (11.8\%) in non-tumor library.

The distribution of relative abundance of 40 representative genera in combined library (Figure 4b) was predominated by Streptococcus (50.8\%), Gemella (11.6\%), Parvimonas (4.6\%), Peptostreptococcus (2.8\%), Xanthomonas (2.4\%), Johnsonella (1.6\%), Solobacterium (1.6\%), Atopobium (1.2\%) and Eubacterium[11][G-1] (0.8\%), in tumor library while Prevotella (11.6\%), Veillonella (9.9\%), Granulicatella (3.9\%), Escherichia coli (2.4\%), Oribacterium (2.2\%), Fusobacterium (1.9\%), Actinomyces (1.4\%), Megasphaera (1.4\%), Afipia (1.2\%) and Leptotrichia (1.0\%) in non-tumor library. Among others, genera Capnocytophaga, Selenomonas and Leptothrix were exclusive to non-tumor (control) tissues and Eubacterium[11][G-3], Campylobacter and Catonella, confined only to tumor tissues. Figure $4 \mathrm{c}$ shows the relative shift from gram-negative to gram-positive microbiota by an increase of $19 \%$ in tumor tissue samples than in control non-tumor samples. Also, it was observed that the two groups shared 25 genera, while 7 genera were exclusive to non-tumor group and 8 genera to tumor group (Figure 4c).

The core of pie chart shows \% distribution of 914 total sequences in terms of \% homology to curated $16 \mathrm{~S}$ rRNA sequences in HOMD (Figure 5). The outer concentric of pie chart depicts total oral bacterial taxa with $>98 \%$ identity contributing to named cultivable species (78.6\%), unnamed cultivable species (5.9\%) and non-cultivable or uncultured phylotypes (3.8\%) and the sequences with $<98 \%$ identity are unclassified species $(11.7 \%)$ characterized only to genus level. These total sequences in RDP showed homology with $\sim 60 \%$ of uncultured phylotypes. Therefore, the sequences analyzed with HOMD were taken into consideration for species level identification. The venn diagrams (Figure 5) are embedded to corresponding section of pie chart except for the unclassified sequences and the inset values in two subsets (non-tumor and tumor) correlates to observed bacterial species unique to that particular library. The number of species shared or common to both the groups is seen in overlapping section of subsets.

In total, 80 bacterial species/phylotypes were detected, 57 in non-tumor and 59 in tumor library. The unnamed 


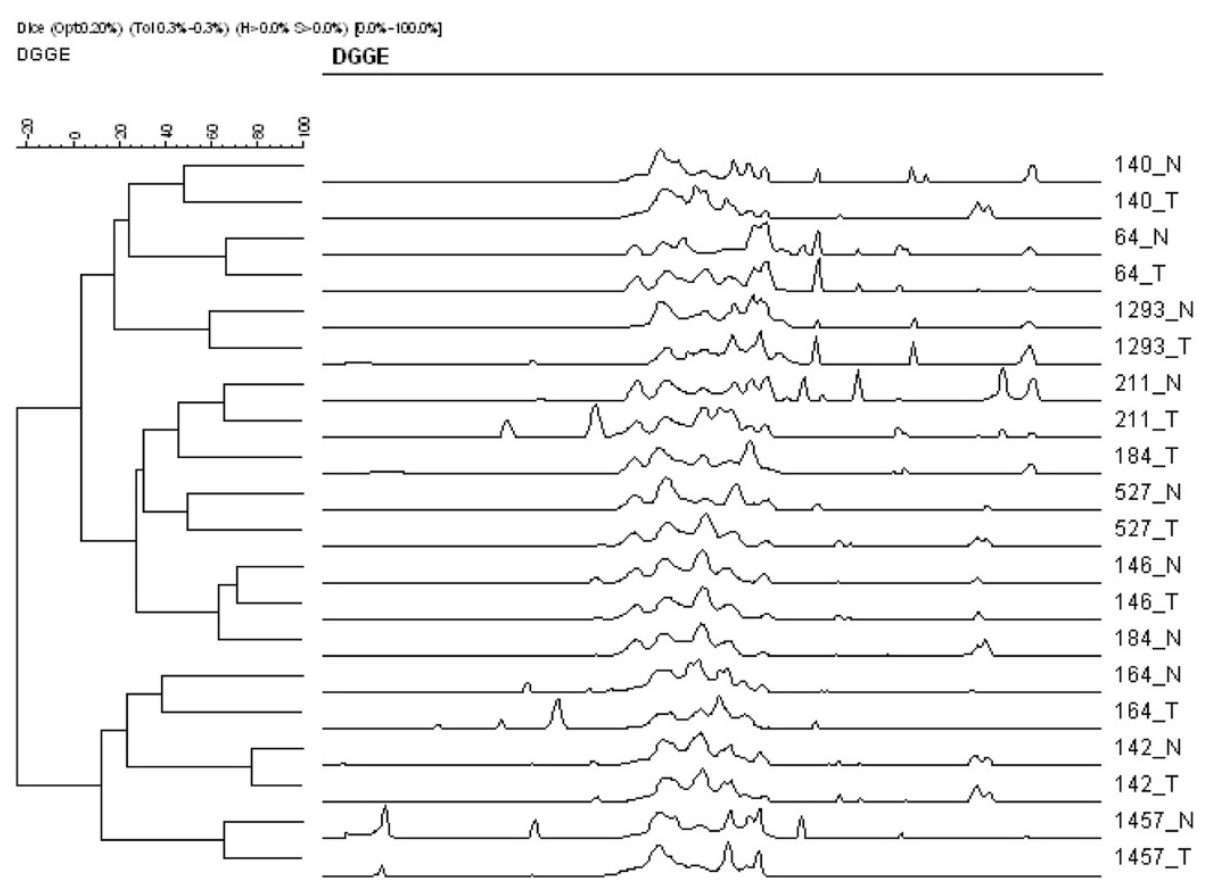

Figure 2 Dendrogram representing the fingerprinting intensity profile of two clinically distinct samples from non-tumor and tumor tissues. N-Non-tumor; T-Tumor.

cultivable biota, Actinomyces sp. oral taxon 181, phylotype Leptotrichia sp. oral taxon 215, and certain named bacterial species, Prevotella histicola, Prevotella melaninogenica, Prevotella pallens, Fusobacterium nucleatum ss. nucleatum, Escherichia coli and Neisseria flavescens were detected at non-tumor site while Atopobium parvulum and Fusobacterium nucleatum ss. vincentii at tumor site (Figure 6a). The microbiota associated with phylum Firmicutes showed interesting switch in profile (Figure 6b). Species, Granulicatella adiacens, Mogibacterium diversum, Parvimonas micra, Streptococcus anginosus, Streptococcus cristatus, Streptococcus mitis and Veillonella dispar were prevalent at non-tumor site of the OSCC patients. The unnamed cultivable taxon, Streptococcus $s p$. oral taxon 058, and named cultivable bacterial species, Gemella haemolysans, Gemella morbillorum, Gemella sanguinis, Johnsonella ignava, Peptostreptococcus stomatis, Streptococcus gordonii, Streptococcus parasanguinis I, Streptococcus salivarius were highly associated to tumor site. Streptococcus $s p$. oral taxon 071 and Selenomonas sputigena were confined to non-tumor site whereas Parvimonas sp. oral taxon 110, Eubacterium [11][G-1] infirmum and Eubacterium [XI][G-3] brachy were exclusive to tumor site. Streptococcus intermedius was the most prevalent species. Streptococcus parasanguinis II and Oribacterium sinus were detected at both sites. Some observed bacterial species/phyloypes were less frequent in OSCC patients.
The species richness, coverage, diversity and evenness were estimated for two independent and combined set of libraries (Table 2). Shannon-Weaver and Simpson diversity indices revealed higher values indicating a huge species diversity in two libraries but no significant differences, Shannon diversity $t$ test, $p=0.07(p>0.05)$. However, the richness estimators, Chao 1 and ACE were higher in tumor library than in non-tumor library. Evenness was greater with non-tumor samples as compared to tumor samples suggesting less abundant species at tumor site. Good's coverage of the combined library was $\sim 98 \%$ suggesting that 2 additional phylotypes would be recognized if 100 more clones were screened. Individual-based rarefaction curves calculated using PAST for the two library sets showed asymptote curve (see Additional file 4: Figure S4a) at actual community richness depicting that libraries were large enough to represent majority of oral bacterial species in the sampled subsets. Rank abundance curves were plotted to compare how well the communities have been sampled (see Additional file 4: Figure S4b). A long right-hand tail indicated rare species with few abundant species in both libraries.

\section{Discussion}

Bacteria have the capacity to penetrate and invade various epithelial cells colonizing and inducing inflammation which may plausibly associate to cancer progression $[63,64]$. For example, $H$. pyroli have been known to be 
Table 1 Similarity index of DGGE fingerprinting pattern from two clinically distinct non-tumor and tumor groups

\begin{tabular}{|c|c|c|c|c|c|c|c|c|c|c|c|c|c|c|c|c|c|c|c|c|}
\hline & \multicolumn{20}{|c|}{ Similarity Index (\%) } \\
\hline & $140 \_N$ & 140_T & 64_N & 64_T & 1293_N & 1293_T & 211_N & 211_T & $184 \_T$ & $527 \_N$ & $527 \_T$ & $146 \_N$ & 146_T & 184_N & 164_N & 164_T & $142 \_N$ & $142 \_T$ & 1457_N & 1457_T \\
\hline $140 \_N$ & 100 & & & & & & & & & & & & & & & & & & & \\
\hline 140_T & 47.83 & 100 & & & & & & & & & & & & & & & & & & \\
\hline 64_N & 35.56 & 35.56 & 100 & & & & & & & & & & & & & & & & & \\
\hline 64_T & 39.13 & 43.48 & 66.67 & 100 & & & & & & & & & & & & & & & & \\
\hline 1293_N & 41.87 & 27.91 & 42.86 & 41.87 & 100 & & & & & & & & & & & & & & & \\
\hline 1293_T & 30 & 30 & 35.9 & 40 & 59.46 & 100 & & & & & & & & & & & & & & \\
\hline 211_N & 31.11 & 31.11 & 36.37 & 44.45 & 38.1 & 30.77 & 100 & & & & & & & & & & & & & \\
\hline 211_T & 50 & 36.37 & 32.56 & 54.55 & 34.15 & 31.58 & 65.12 & 100 & & & & & & & & & & & & \\
\hline 184_T & 41.87 & 27.91 & 33.33 & 37.21 & 50 & 32.43 & 42.86 & 58.54 & 100 & & & & & & & & & & & \\
\hline 527_N & 36.37 & 45.46 & 46.51 & 50 & 39.03 & 36.85 & 41.87 & 42.86 & 39.03 & 100 & & & & & & & & & & \\
\hline 527_T & 42.11 & 31.58 & 32.43 & 42.11 & 34.29 & 31.25 & 43.25 & 44.45 & 45.72 & 50 & 100 & & & & & & & & & \\
\hline 146_N & 27.27 & 54.55 & 37.21 & 50 & 34.15 & 21.05 & 32.56 & 47.62 & 48.78 & 52.39 & 44.45 & 100 & & & & & & & & \\
\hline 146_T & 36.37 & 54.55 & 37.21 & 54.55 & 34.15 & 26.32 & 55.81 & 57.15 & 48.78 & 42.86 & 50 & 71.43 & 100 & & & & & & & \\
\hline 184_N & 31.11 & 35.56 & 27.27 & 40 & 28.57 & 20.51 & 45.46 & 51.17 & 47.62 & 51.17 & 32.43 & 65.12 & 65.12 & 100 & & & & & & \\
\hline 164_N & 20.41 & 36.74 & 29.17 & 28.57 & 26.09 & 37.21 & 25 & 25.53 & 26.09 & 12.77 & 19.51 & 38.3 & 12.77 & 33.33 & 100 & & & & & \\
\hline 164_T & 24.49 & 28.57 & 20.83 & 24.49 & 21.74 & 27.91 & 16.67 & 21.28 & 21.74 & 17.03 & 24.39 & 21.28 & 25.53 & 16.67 & 38.47 & 100 & & & & \\
\hline $142 \_N$ & 34.05 & 34.05 & 30.44 & 25.53 & 31.82 & 43.91 & 17.39 & 35.56 & 40.91 & 13.33 & 30.77 & 40 & 35.56 & 30.44 & 56.01 & 36.01 & 100 & & & \\
\hline $142 \_\mathrm{T}$ & 32.56 & 46.51 & 33.33 & 32.56 & 40 & 27.03 & 33.33 & 43.91 & 40 & 24.39 & 51.43 & 68.29 & 53.66 & 47.62 & 26.09 & 34.79 & 77.27 & 100 & & \\
\hline 1457_N & 43.48 & 21.74 & 22.23 & 21.74 & 41.87 & 30 & 22.23 & 36.37 & 41.87 & 18.19 & 31.58 & 31.82 & 22.73 & 31.11 & 36.74 & 40.82 & 46.81 & 41.87 & 100 & \\
\hline 1457_T & 13.95 & 18.61 & 23.81 & 18.61 & 15 & 27.03 & 14.29 & 14.64 & 20 & 9.76 & 0 & 19.51 & 19.51 & 14.29 & 30.44 & 26.09 & 36.37 & 15 & 65.12 & 100 \\
\hline
\end{tabular}

N-Non-tumor; T-Tumor. 


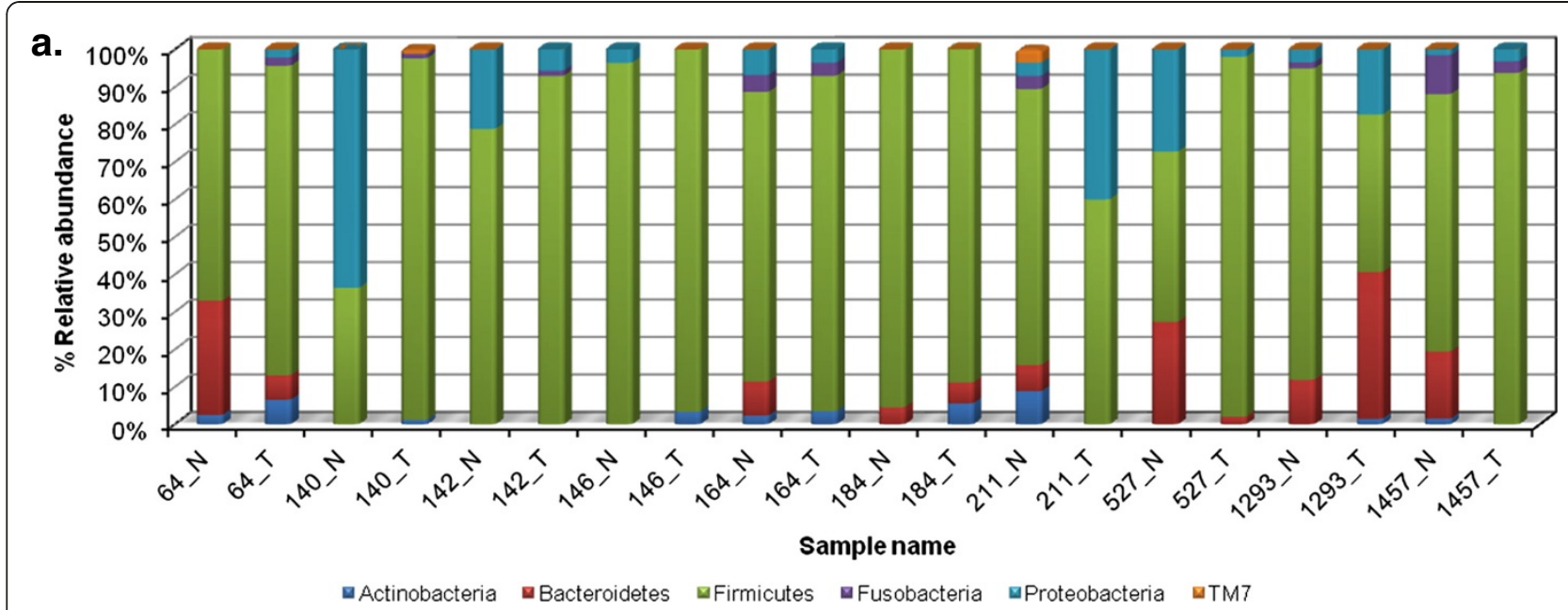

b.

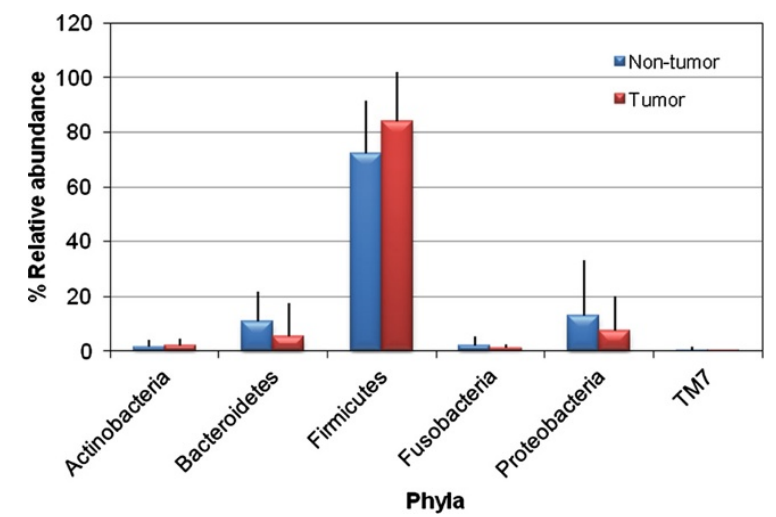

Figure 3 Distribution of relative abundance of phyla in (a) Individual sample set, non-tumor and tumor sites of each OSCC patient and; (b) Cumulative non-tumor and tumor libraries, as detected by HOMD and RDP. N-Non-tumor; T-Tumor.

associated to inflammation of gastric mucosa leading to gastritis, peptic ulcers, gastric carcinoma and gastric mucosa-associated lymphoid tissue (MALT) lymphomas [18]. Recently, a link between periodontal disease and cancer has been suggested and the hypothetical proposition is the chronic nature of inflammatory process underlying periodontitis $[64,65]$. To the best of our knowledge, this is the first report using DGGE in parallel to sequencing for profiling bacterial flora and compares the diversity in non-tumor and tumor tissues from same individual. Here, we used homogenous population to control various confounding factors and hence did not compare bacterial colonization within healthy individuals but screened the normal mucosa collected from the same subject. Thus the role of microbes in oral diseases can be predicted looking at the changes in indigenous (non-tumor) and diseased (tumor) microenvironments. DGGE allows rapid assessment of bacterial diversity in various environments and we have extensively used this technique in our earlier studies on saliva and cariogenicity $[45,51,52]$. The fingerprints represents separation of DNA fragments of same length based on differences in nucleotide and each individual band relates to one or more bacterial species [66].

In this study, the observed differences in DGGE profiles of inter- group, $22.73 \%-90.24 \%$ among non-tumor and tumor groups, and intra- group diversity, $34.88 \%-$ $87.23 \%$ within non-tumor group and $41.46 \%-100 \%$ within tumor group, signified some underlying changes in bacterial colonization of the tissues. Thus, even slight differences in bacterial profile of non-tumor and tumor tissues seem significant as samples were procured from the same individual. It is not surprising that fingerprints showed no significant differences in mean total number of bands. DGGE is a semi-quantitative method and the band intensities are also influenced by $16 \mathrm{~S}$ rRNA gene copy numbers or co-migration of two or more sequence types or combination of these $[67,68]$. However, the relative distribution of more intense bands may represent species indigenous and abundant in oral microenvironment. The less intense bands indicated indigenous but less rich species or species in low numbers. Some species that were 


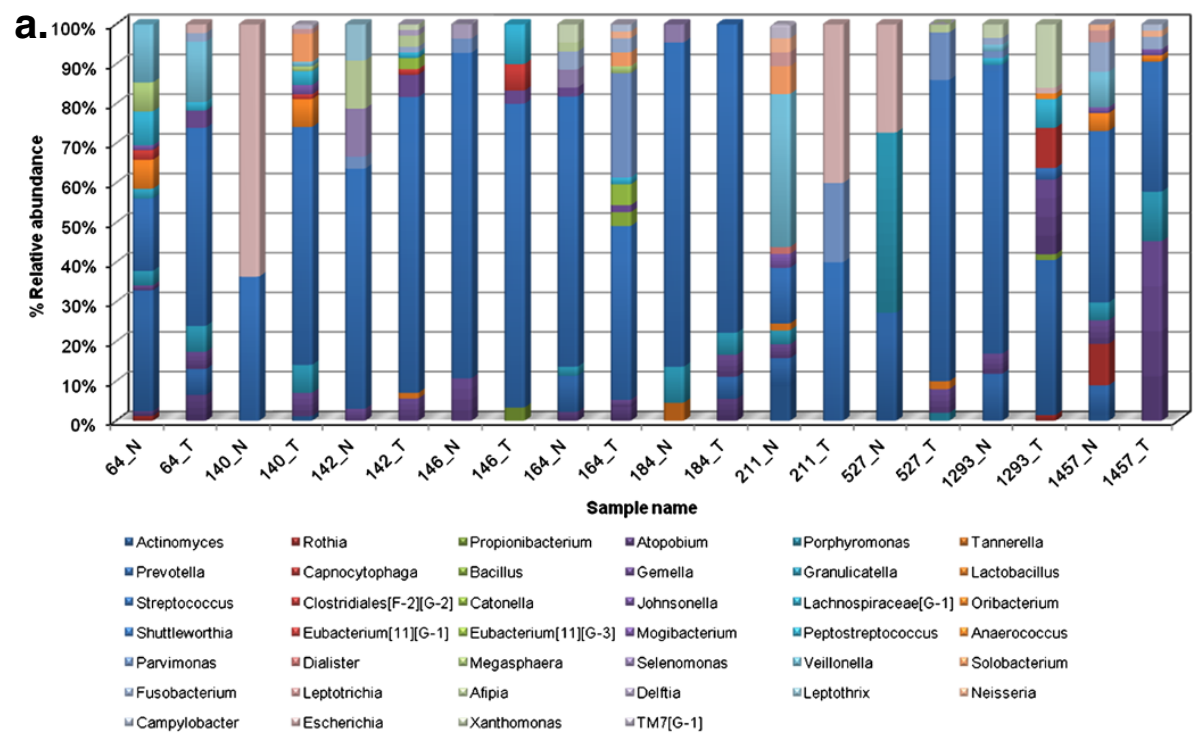

b.

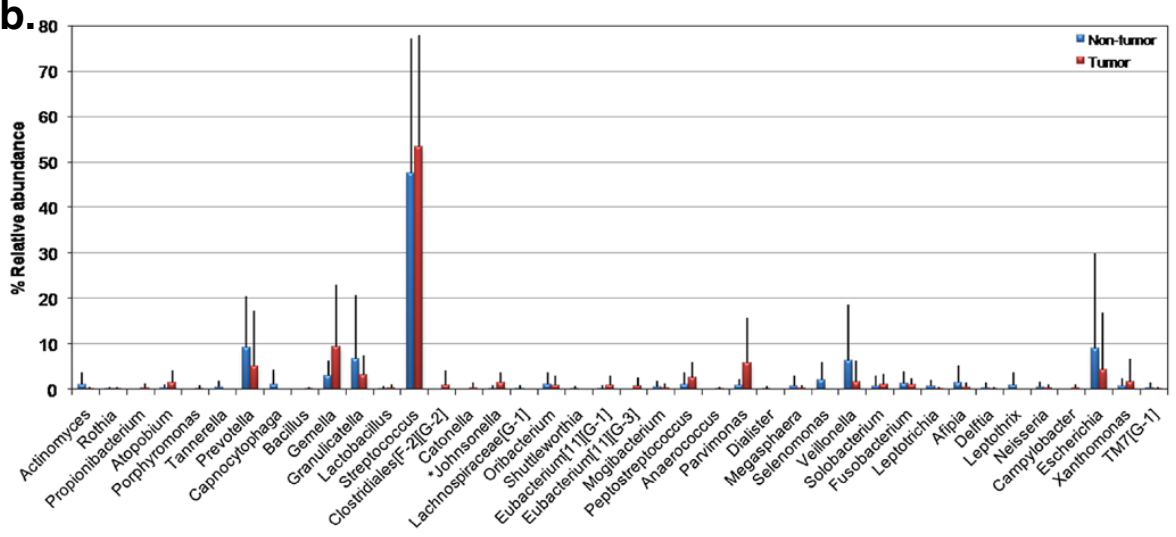

C.

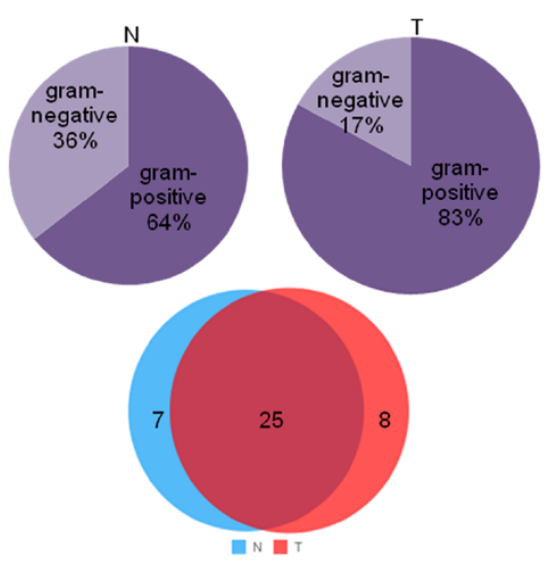

Figure 4 Distribution of relative abundance of genera at (a) Non-tumor and tumor sites of each OSCC subject; and (b) Cumulative non-tumor and tumor libraries, as detected by HOMD and RDP; (c) Pie-chart shows the relative prevalence of gram-negative and gram-positive bacteria and venn diagram depicts the genera in tissue samples of OSCC subjects. ${ }^{*} p<0.1$. N-Non-tumor; T-Tumor. Pie-chart shows the relative shift of gram-negative and gram-positive microbiota in non-tumor and tumor tissue samples. Values in the venn diagram represent the genera shared by and exclusive to non-tumor and tumor tissue libraries. 


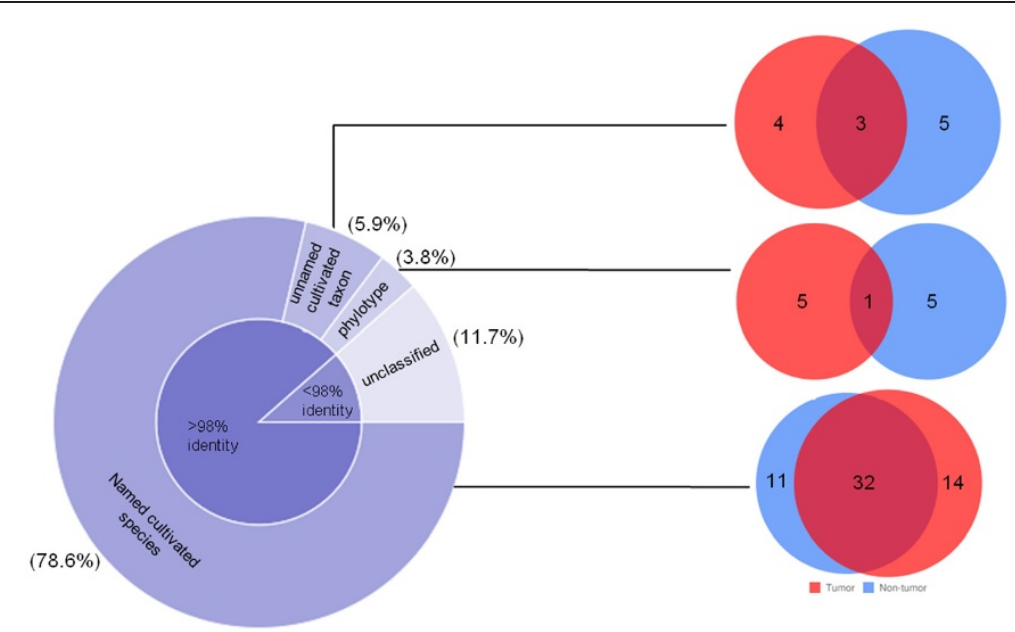

Figure 5 Relative distribution of total bacteria (cultivable species and uncultured phylotypes) in tissues from non-tumor and tumor sites of OSCC subjects characterized by HOMD. Core of pie chart shows percentage distribution of total 914 filtered sequences in terms of their \% homology to curated $16 \mathrm{~S}$ rRNA sequences in HOMD. Outer concentric of pie chart depicts the oral bacterial taxa in combined library; sequences with $>98 \%$ identity: named cultured species (78.6\%), unnamed cultured species (5.9\%) and yet-uncultured phylotypes (3.8\%); and sequences with $<98 \%$ identity (11.7\%) were considered as unclassified sequences characterized only to genus level. Venn diagrams correlates with the corresponding section of pie chart as indicated by line except for the unclassified sequences. Inset values in two subsets (non-tumor and tumor) represents observed bacterial species unique to that particular library. Values in overlapping section of subsets reflect oral taxa common to both sites.

found to be higher in one group were either less abundant or even absent in other group. This indicates close interactions within the microbial communities' along with relative microbial shift at two target sites. Our earlier study on DGGE fingerprints of saliva samples from OSCC and healthy subjects have shown significant group-specific clusters despite inter- subject variability that may enable to differentiate OSCC from healthy subjects [40].

This was further substantiated by the results of $16 \mathrm{~S}$ clonal analysis showing relatively distinct bacterial affiliations at non-tumor and tumor sites of OSCC subjects. Firmicutes were highly prevalent at tumor site as observed earlier $[37,38,40]$. About 25 genera were common to both sites. There were differences in the relative abundance of bacteria, however, no statistically significant differences in phylogenies were detected at tumor and non-tumor sites of the OSCC patients except for genus Johnsonella $(p<0.1)$. The bacterial species associated with tumor tissues were far more diverse than that previously shown by culture-dependent [10,33-36] and culture-independent studies [38]. The predominance of gram-positive bacteria relative to gram-negative bacteria suggests differences in the bacterial communities at two clinically distinctive sites. These oral bacteria may act as a primary trigger or precursor of mucosal lesions or secondary invaders in non-infectious mucosal lesions [33].

An interesting observation related to clonal analysis was that the sequences when matched with the two known databases, RDP and HOMD for highest similarity showed similar results up to genus level. But at species level, the uncultivable phylotypes detected were $3.83 \%$ and $\sim 60 \%$ by HOMD and RDP respectively. This may be due to differences in basic structure of two databases. Unlike RDP, HOMD is a curated database with 626 species and phylotypes based on $98.5 \%$ similarity cutoffs of full 1540-base 16S rRNA sequences and each oral taxon assigned a specific number.

Most of the cultivable bacteria, Actinomyces sp. oral taxon 181, Streptococcus sp. oral taxon 071, P. histicola, P. pallens, Selenomonas sputigena, $V$. dispar and phylotype, Leptotrichia sp. oral taxon 215 present in non-tumor tissues are known putative representatives of predominant genera in healthy oral microbiome [69]. Prevotella has earlier been associated with different types of endodontic infections [70] and Leptotrichia an opportunistic pathogen with bacteremia or sepsis producing lactic acid as a major metabolic end product [71]. Granulicatella adiacens which was highly prevalent in non-tumor group is also a known agent of endocarditis [72]. S. intermedius was predominant in $70 \%$ of OSCC subjects at both nontumor and tumor sites. S. parasangunis II and O. sinus were also present at both sites. Oribacterium species are weakly fermentative forming metabolic end products, acetic and lactic acid [73]. S. anginosus detected at 4 nontumor and 2 tumor sites has been reported earlier in OSCC specimens [36,38] and saliva of alcoholics [74]. The Streptococcus anginosus group comprised of three species, S. anginosus, S. constellatus and S. intermedius 


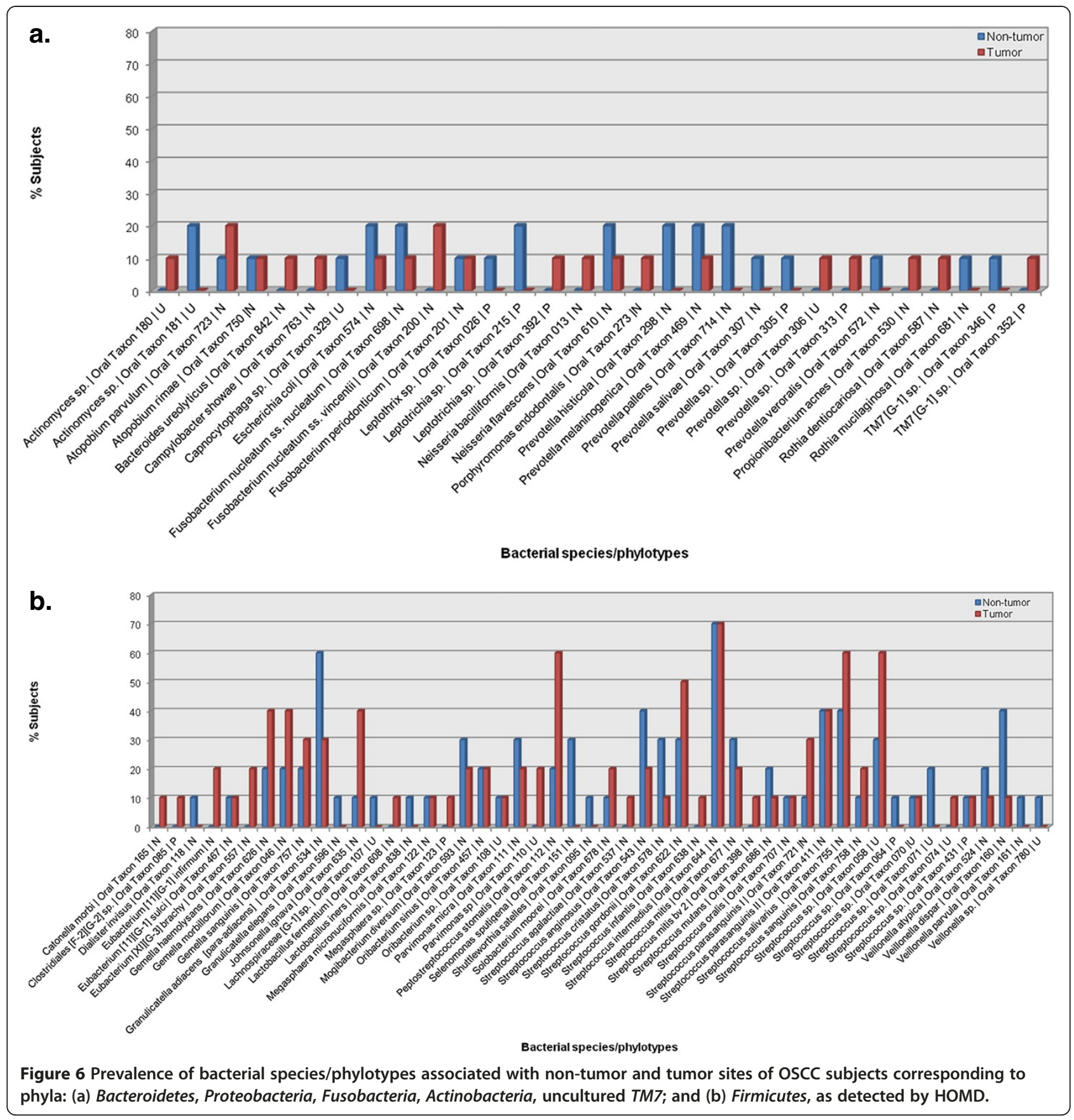

and are normal flora in humans, these bacteria are pathogens associated strongly with abscess formation and with infection in multiple body sites [75]. Assacharolytic Eubacterium and closely related strains found in our study at tumor sites are major bacterial groups in oral lesions and play important role in infections of root canal and periodontal pockets and use proteins and peptides derived from tissues and blood as energy source [76]. Also, Atopobium, F. nucleatum ss. vincentii and Parvimonas have been associated with endodontic infections or periodontitis $[40,77,78]$. Together, these observed species at tumor sites substantiates its association with some early primary infection of lesion that may act as a trigger for tumor initiation and progression [79].

Streptococci were more prevalent at tumor sites as also reported earlier $[10,34,35,80]$. We observed Streptococcus $s p$. oral taxon 058, Peptosteptococcus stomatis, S. salivarius, S. gordonii, G. haemolysans, G. morbillorum, J. ignava and $S$. parasanguinis $I$, to be associated with tumor site. Van 
Table 2 Richness, diversity indices and coverage estimation in individual and combined libraries

\begin{tabular}{|c|c|c|c|}
\hline & $\mathbf{N}$ & $\mathrm{T}$ & Combined \\
\hline & $\overline{(n=10)}$ & $\overline{(n=10)}$ & $(n=20)$ \\
\hline No. of clones & 414 & 500 & 914 \\
\hline Species/phylotypes (S) & 57 & 59 & 80 \\
\hline Singletons & 16 & 22 & 21 \\
\hline Doubletons & 9 & 7 & 13 \\
\hline Chaol estimator of species richness & 71.22 & 93.57 & 96.96 \\
\hline Chao1 standard deviation & 9.34 & 20.56 & 9.69 \\
\hline ACE estimator of species richness & 68.59 & 83.76 & 97.78 \\
\hline Shannon's index for diversity $(\mathrm{H})$ & 3.37 & 3.20 & 3.47 \\
\hline Simpson's index for diversity (1-D) & 0.94 & 0.92 & 0.94 \\
\hline Evenness $\left(\mathrm{e}^{\wedge} \mathrm{H} / \mathrm{S}\right)$ & 0.51 & 0.42 & 0.40 \\
\hline Good's estimator of coverage (\%) & 96.14 & 95.6 & 97.7 \\
\hline
\end{tabular}

N-non-tumor; T-tumor; Combined-non-tumor and tumor; n-number of samples.

Houte et al. [81,82] identified significant populations of Streptococci which produced large amounts of acid ( $\mathrm{pH}<4.2$ in broth) in both coronal caries and rootsurface caries. Streptococci are saccharolytic producing short chain organic acid from carbohydrates, thus lowering the $\mathrm{pH}$ of their local environment [83] and also aciduric $P$. stomatis found in oral cavity is weakly saccharolytic and produces fermented products, acetic, butyric, isobutyric, isovaleric and isocaproic acids [84]. These microbiota may contribute to the acidic and hypoxic microenvironment of tumors $[85,86]$ and promote bacterial colonization. Anaerobes, Gemella species like any other commensal are opportunistic pathogens known to cause serious local and systemic infections mainly in immune-suppressed patients $[40,87]$ were detected at tumor sites $[35,40]$. J. ignava can be a predicted new pathogen not detected in earlier studies and known to be associated with gingivitis and periodontitis [88].

Studies have shown association of tooth loss or periodontal diseases and oral cancer [89-91]. Periodontal disease is often linked to cardiovascular disease, lowbirth weight complications in pregnancy, diabetes and pulmonary disease and certain cancers including oral cancer [79]. The common factor between periodontal disease and cancer is inflammation driven by bacteria. At this point of time, it is not clear whether changes in bacterial colonization act as a trigger to lesion formation. However, once the lesion is formed which may be spontaneous or due to underlying changes in the host tissues as a result of external factors such as smoking, drinking or oral health, specific oral bacteria can colonize and induce inflammation. Oral bacteria have shown ability to adhere, co-aggregate or colonize on specific surfaces in oral cavity representing tissue tropism as reported in several studies $[92,93]$.

The involvement of infection-triggered inflammations has been estimated in the pathogenesis of approximately $15-20 \%$ of human tumors $[17,94]$. Recently, it has been shown that two specific bacterial subpopulations, Enterobacteriaceae and Tenericutes lead to increase in methylation of multidrug resistance gene1 (MDR1 gene) and bacterial-triggered inflammation that correlates with regional nodal metastases over adjacent normal mucosa [63].

Mager et al. [93] demonstrated significant differences in the bacterial profiles of 40 oral cultivable species on soft and hard tissues in healthy subjects and found distinct profiles of the soft tissues than those of supragingival and subgingival plaques. Using culture-independent molecular technique, Aas et al. [92] analyzed samples of nine sites from five healthy subjects and showed the site and subject specificity of bacterial colonization in the healthy human oral cavity. In our study too, despite the homogenous population, several species were site-specific, while others were subject-specific and undergo succession from health to disease. Hence, even a slight distinction in bacterial community at non-tumor and tumor sites has significance as the samples were from two adjoining sites of same OSCC subject. The underlying species-specific shift implicates alterations in bacterial colonization at tumor sites. The translocation of bacteria from oral cavity to cervical lymph nodes and more in metastatic than in uninvolved nodes in oral cancer patients has been reported by Sakamoto et al. [35].

\section{Conclusions}

Together, the results indicate that certain bacterial species/phylotypes detected in this study may play a role in triggering chronic inflammation in oral cavity and possibly be associated at different stages of cancer [95]. This may be due to disrupted oral mucosal surface allowing bacterial invasion and perhaps serve as point of entry to the regional lymph nodes $[33,35]$. This indicates that though the bacterial biota were commensals of oral cavity and may become pathogenic when their balance is disturbed. Microbial shift or dysbiosis has been implicated in some diseases due to unequal ratio of beneficial symbionts to pathogens [96]. This study recognized association of some new bacterial species, like J. ignava not detected earlier in tumor samples by culturedependent or independent methods. However, these studies were performed with limited sample size. Therefore, further investigation with larger sample size using high throughput sequencing would validate these findings and broaden our perspective on bacterial association and oral cancer. 


\section{Additional file}

Additional file 1: Figure S1. Distribution of relative abundance of classes detected by HOMD and RDP in tissue samples from non-tumor and tumor sites of OSCC subjects.

Additional file 2: Figure S2. Distribution of relative abundance of order detected by HOMD and RDP in tissue samples from non-tumor and tumor sites of OSCC subjects.

Additional file 3: Figure S3. Distribution of relative abundance of families detected by HOMD and RDP in tissue samples from non-tumor and tumor sites of OSCC subjects.

Additional file 4: Figure S4. (a) Individual-based rarefaction; and (b) Rank abundance curves for bacterial species associated with nontumor tissue and tumor tissue libraries.

\section{Competing interests}

The authors declare that they have no competing interests.

\section{Acknowledgements}

This work was supported by NIDCR Grants DE019178 and DE020891.

\section{Author details}

${ }^{1}$ Department of Basic Sciences and Craniofacial Biology, New York University College of Dentistry, 345 E, 24th Street, Room 921B, New York, NY 10010,

USA. ${ }^{2}$ Department of Chemical and Biological Sciences, Polytechnic Institute of NYU, New York, NY, USA. ${ }^{3}$ Dental Service, Department of Surgery, Memorial Sloan-Kettering Cancer Center, New York, NY, USA. ${ }^{4}$ Laboratory of Epithelial Cancer Biology, Memorial Sloan-Kettering Cancer Center, New York, NY, USA.

\section{Authors' contributions}

SP participated in the design, implementation, analysis, interpretation of the results and writing the manuscript. XJ participated in implementation and analysis. YL participated in analysis of DGGE profiles. CE, RY and BS participated in collecting and providing the samples. $\mathrm{XL}$ participated in interpretation of the results and writing the manuscript. DS conceived of the study and participated in the design, implementation, analysis, interpretation of the results and writing the manuscript. All authors read and approved the final manuscript.

Received: 10 February 2012 Accepted: 20 July 2012

Published: 20 July 2012

\section{References}

1. Bagan J, Sarrion G, Jimenez Y: Oral cancer: clinical features. Oral Oncol 2010, 46(6):414-417.

2. Rosenquist $\mathrm{K}$ : Risk factors in oral and oropharyngeal squamous cell carcinoma: a population-based case-control study in southern Sweden. Swed Dent J Supp/ 2005, 179:1-66.

3. Scully C, Bagan J: Oral squamous cell carcinoma: overview of current understanding of aetiopathogenesis and clinical implications. Oral Dis 2009, 15(6):388-399.

4. Altekruse SF KC, Krapcho M, Neyman N, Aminou R, Waldron W, Ruhl J Howlader N, Tatalovich Z, Cho H, eds, et al (Eds): SEER Cancer Statistics Review, 1975-2008. Bethesda, MD: National Cancer Institute; 1975-2008. posted to the SEER web site, 2011, based on November 2010 SEER data submission.

5. Johnson NW, Jayasekara P, Amarasinghe AAHK: Squamous cell carcinoma and precursor lesions of the oral cavity: epidemiology and aetiology. Periodonto/ 2011, 57(1):19-37.

6. Tanaka T, Tanaka M, Tanaka T: Oral carcinogenesis and oral cancer chemoprevention: a review. Pathol Res Int 2011 2011, 10 pages. Article ID 431246, doi:10.4061/2011/431246.

7. Tsantoulis PK, Kastrinakis NG, Tourvas AD, Laskaris G, Gorgoulis VG: Advances in the biology of oral cancer. Oral Oncol 2007, 43(6):523-534.

8. Lax AJ, Thomas W: How bacteria could cause cancer: one step at a time. Trends Microbiol 2002, 10(6):293-299.
9. Pujol FH, Devesa M: Genotypic variability of hepatitis viruses associated with chronic infection and the development of hepatocellular carcinoma. J Clin Gastroenterol 2005, 39(7):611-618.

10. Nagy KN, Sonkodi I, Szoke I, Nagy E, Newman HN: The microflora associated with human oral carcinomas. Oral Oncol 1998, 34(4):304-308

11. Sharma Mohit Bairy I, Pai K, Satyamoorthy K, Prasad S, Berkovitz B, Radhakrishnan R: Salivary IL-6 levels in oral leukoplakia with dysplasia and its clinical relevance to tobacco habits and periodontitis. Clin Oral Invest 2010, 15(5):705-714.

12. Tezal M, Sullivan MA, Hyland A, Marshall JR, Stoler D, Reid ME, Loree TR, Rigual NR, Merzianu M, Hauck L, et al: Chronic periodontitis and the incidence of head and neck squamous cell carcinoma. Cancer Epidemiol Biomarkers Prev 2009, 18(9):2406-2412.

13. Lissowska J, Pilarska A, Pilarski P, Samolczyk-Wanyura D, Piekarczyk J, Bardin-Mikollajczak A, Zatonski W, Herrero R, Munoz N, et al: Smoking, alcohol, diet, dentition and sexual practices in the epidemiology of oral cancer in Poland. Eur J Cancer Prev 2003, 12(1):25-33.

14. Hooper SJ, Wilson MJ, Crean SJ: Exploring the link between microorganisms and oral cancer: a systematic review of the literature. Head Neck 2009, 31(9):1228-1239.

15. Lax AJ: Opinion: bacterial toxins and cancer-a case to answer? Nat Rev Microbiol 2005, 3(4):343-349.

16. Mantovani A, Garlanda C, Allavena P: Molecular pathways and targets in cancer-related inflammation. Ann Med 2010, 42(3):161-170.

17. Meurman J: Oral microbiota and cancer. J Oral Microbiol 2010, 2:5195. doi:10.3402/jom.v2i0.5195.

18. Tsai HF, Hsu PN: Interplay between Helicobacter pylori and immune cells in immune pathogenesis of gastric inflammation and mucosal pathology. Cell Mol Immunol 2010, 7(4):255-259.

19. Mager DL: Bacteria and cancer: cause, coincidence or cure? a revie. J Transl Med 2006, 4:14.

20. Vogelmann R, Amieva MR: The role of bacterial pathogens in cancer Curr Opin Microbiol 2007, 10(1):76-81.

21. Ward JM, Fox JG, Anver MR, Haines DC, George CV, Collins MJ Jr, Gorelick PL, Nagashima K, Gonda MA, Gilden RV, et al: Chronic active hepatitis and associated liver tumors in mice caused by a persistent bacterial infection with a novel Helicobacter species. J Natl Cancer Inst 1994, 86(16):1222-1227.

22. Engle SJ, Ormsby I, Pawlowski S, Boivin GP, Croft J, Balish E, Doetschman T: Elimination of colon cancer in germ-free transforming growth factor beta 1-deficient mice. Cancer Res 2002, 62(22):6362-6366.

23. Rao VP, Poutahidis T, Fox JG, Erdman SE: Breast cancer: should gastrointestinal bacteria be on our radar screen? Cancer Res 2007 67(3):847-850.

24. Kuper $\mathrm{H}$, Adami HO, Trichopoulos D: Infections as a major preventable cause of human cancer. J Int Med 2000, 248:171-183.

25. Coussens LM, Werb Z: Inflammation and cancer. Nature 2002, 420(6917):860-867.

26. Eskan MA, Hajishengallis G, Kinane DF: Differential activation of human gingival epithelial cells and monocytes by Porphyromonas gingivalis fimbriae. Infect Immun 2007, 75(2):892-898.

27. Fukata M, Hernandez Y, Conduah D, Cohen J, Chen A, Breglio K, Goo T, Hsu D, Xu R, Abreu MT: Innate immune signaling by Toll-like receptor-4 (TLR4) shapes the inflammatory microenvironment in colitis-associated tumors. Inflamm Bowel Dis 2009, 15(7):997-1006

28. Califano J, van der Riet P, Westra W, Nawroz H, Clayman G, Piantadosi S, Corio R, Lee D, Greenberg B, Koch W, et al: Genetic progression model for head and neck cancer: implications for field cancerization. Cancer Res 1996, 56(11):2488-2492.

29. Chen Z, Malhotra PS, Thomas GR, Ondrey FG, Duffey DC, Smith CW, Enamorado I, Yeh NT, Kroog GS, Rudy S, et al: Expression of proinflammatory and proangiogenic cytokines in human head and neck cancer patients. Head Neck 1998, 20:450.

30. De Schutter H, Landuyt W, Verbeken E, Goethals L, Hermans R, Nuyts S: The prognostic value of the hypoxia markers CA IX and GLUT 1 and the cytokines VEGF and IL 6 in head and neck squamous cell carcinoma treated by radiotherapy \pm chemotherapy. BMC Cancer 2005, 5:42.

31. Rhodus NL, Ho V, Miller CS, Myers S, Ondrey F: NF-kappaB dependent cytokine levels in saliva of patients with oral preneoplastic lesions and oral squamous cell carcinoma. Cancer Detect Prev 2005, 29(1):42-45. 
32. Kroes I, Lepp PW, Relman DA: Bacterial diversity within the human subgingival crevice. PNAS 1999, 96(25):14547-14552.

33. Nagy K, Szoke I, Sonkodi I, Nagy E, Mari A, Szolnoky G, Newman HN: Inhibition of microflora associated with oral malignancy. Oral Oncol 2000, 36(1):32-36

34. Hooper SJ, Crean SJ, Lewis MA, Spratt DA, Wade WG, Wilson MJ: Viable bacteria present within oral squamous cell carcinoma tissue. J Clin Microbiol 2006, 44(5):1719-1725.

35. Sakamoto H, Sasaki J, Nord CE: Association between bacterial colonization on the tumor, bacterial translocation to the cervical lymph nodes and subsequent postoperative infection in patients with oral cancer. Clin Microbiol Infect 1999, 5(10):612-616.

36. Sasaki M, Yamaura C, Ohara-Nemoto Y, Tajika S, Kodama Y, Ohya T, Harada R, Kimura S: Streptococcus anginosus infection in oral cancer and its infection route. Oral Dis 2005, 11(3):151-156.

37. Ahn J, Yang L, Paster BJ, Ganly I, Morris L, Pei Z, Hayes RB: Oral microbiome profiles: $16 \mathrm{~S}$ rRNA pyrosequencing and microarray assay comparison. PLoS One 2011, 6(7):e22788

38. Hooper SJ, Crean SJ, Fardy MJ, Lewis MA, Spratt DA, Wade WG, Wilson MJ: A molecular analysis of the bacteria present within oral squamous cell carcinoma. J Med Microbio/ 2007, 56(12):1651-1659.

39. Mager DL, Haffajee AD, Devlin PM, Norris CM, Posner MR, Goodson JM: The salivary microbiota as a diagnostic indicator of oral cancer: a descriptive, non-randomized study of cancer-free and oral squamous cell carcinoma subjects. J Transl Med 2005, 3:27.

40. Pushalkar S, Mane SP, Ji X, Li Y, Evans C, Crasta OR, Morse D, Meagher R, Singh A, Saxena D: Microbial diversity in saliva of oral squamous cell carcinoma. FEMS Immunol Med Microbiol 2011, 61(3):269-277.

41. Estilo C, O-charoenrat P, Talbot S, Socci N, Carlson D, Ghossein R, Williams T, Yonekawa Y, Ramanathan Y, Boyle J, et al: Oral tongue cancer gene expression profiling: identification of novel potential prognosticators by oligonucleotide microarray analysis. BMC Cancer 2009, 9(1):11.

42. Estilo CL, O-charoenrat P, Ngai I, Patel SG, Reddy PG, Dao S, Shaha AR Kraus DH, Boyle JO, Wong RJ, et al: The role of novel oncogenes squamous cell carcinoma-related oncogene and phosphatidylinositol 3-kinase p110alpha in squamous cell carcinoma of the oral tongue. Clin Cancer Res 2003, 9(6):2300-2306.

43. Singh B, Reddy PG, Goberdhan A, Walsh C, Dao S, Ngai I, Chou TC, O-charoenrat $P$, Levine AJ, Rao PH, et al: p53 regulates cell survival by inhibiting PIK3CA in squamous cell carcinomas. Genes Dev 2002, 16(8):984-993.

44. Ji X, Pushalkar S, Li Y, Glickman R, Fleisher K, Saxena D: Antibiotic effects on bacterial profile in osteonecrosis of the jaw. Oral Dis 2012, 18(1):85-95.

45. Li Y, Ge Y, Saxena D, Caufield PW: Genetic profiling of the oral microbiota associated with severe early-childhood caries. J Clin Microbiol 2007, 45(1):81-87

46. Eden PA, Schmidt TM, Blakemore RP, Pace NR: Phylogenetic analysis of Aquaspirillum magnetotacticum using polymerase chain reactionamplified 16S rRNA-Specific DNA. Int J Syst Bacteriol 1991, 41(2):324-325.

47. Gee JE, Sacchi CT, Glass MB, De BK, Weyant RS, Levett PN, Whitney AM, Hoffmaster AR, Popovic T: Use of 16S rRNA gene sequencing for rapid identification and differentiation of Burkholderia pseudomallei and $B$. mallei. J Clin Microbio/ 2003, 41(10):4647-4654

48. Lane D: $16 \mathrm{~S} / 23 \mathrm{~S}$ rRNA sequencing. In Nucleic acid techniques in bacterial systematics. Edited by Stackebrandt E, Goodfellow M. West Sussex: John Wiley \& Sons Ltd; 1991:115-147.

49. Rupf S, Merte K, Eschrich K: Quantification of bacteria in oral samples by competitive polymerase chain reaction. J Dent Res 1999 78(4):850-856

50. Zoetendal EG, Akkermans ADL, De Vos WM: Temperature gradient gel electrophoresis analysis of 16s rRNA from human fecal samples reveals stable and host-specific communities of active bacteria. Appl Environ Microbiol 1998, 64(10):3854-3859.

51. Li Y, Ku CY, Xu J, Saxena D, Caufield PW: Survey of oral microbial diversity using PCR-based denaturing gradient gel electrophoresis. J Dent Res 2005, 84(6):559-564.

52. Li Y, Saxena D, Barnes VM, Trivedi HM, Ge Y, Xu T: Polymerase chain reaction-based denaturing gradient gel electrophoresis in the evaluation of oral microbiota. Oral Microbiol Immunol 2006, 21(5):333-339.
53. Larkin MA, Blackshields G, Brown NP, Chenna R, McGettigan PA, McWilliam H, Valentin F, Wallace IM, Wilm A, Lopez R, et al: Clustal W and Clustal X version 2.0. Bioinformatics 2007, 23(21):2947-2948.

54. DeSantis TZ, Hugenholtz P, Keller K, Brodie EL, Larsen N, Piceno YM, Phan R, Andersen GL: NAST: a multiple sequence alignment server for comparative analysis of 16 S rRNA genes. Nucleic Acids Res 2006, 34:W394-W399.

55. Huber T, Faulkner G, Hugenholtz P: Bellerophon; a program to detect chimeric sequences in multiple sequence alignments. Bioinformatics 2004, 20:2317-2319.

56. Chen T, Yu W-H, Izard J, Baranova OV, Lakshmanan A, Dewhirst FE: The Human Oral Microbiome Database: a web accessible resource for investigating oral microbe taxonomic and genomic information. Database 2010, Article ID baq013, doi:10.1093/database/baq013.

57. Dewhirst FE, Chen T, Izard J, Paster BJ, Tanner ACR, Yu W-H, Lakshmanan A, Wade WG: The human oral microbiome. J Bacteriol 2010, 192(19):5002-5017.

58. Tanner ACR, Mathney JMJ, Kent RL, Chalmers NI, Hughes CV, Loo CY, Pradhan N, Kanasi E, Hwang J, Dahlan MA, et al: Cultivable anaerobic microbiota of severe early childhood caries. J Clin Microbiol 2011, 49(4):1464-1474

59. Cole JR, Wang Q, Cardenas E, Fish J, Chai B, Farris RJ, Kulam-Syed-Mohideen AS, McGarrell DM, Marsh T, Garrity GM, et al: The Ribosomal Database Project: improved alignments and new tools for rRNA analysis. Nucleic Acids Res 2009, 37:D141-145.

60. Colwell RK: EstimateS: statistical estimation of species richness and shared species from samples. Version 8.2, 2009. User's guide and application published at: http://purl.oclc.org/estimates.

61. Hammer O, Harper D, Ryan P: PAST: palaeontological statistics software package for education and data analysis. Palaeontol Electron 2001, 4:1-9.

62. Good I: The population frequencies of species and the estimation of population parameters. Biometrika 1953, 40:237-264.

63. Bebek G, Bennett KL, Funchain P, Campbell R, Seth R, Scharpf J, Burkey B, Eng C: Microbiomic subprofiles and MDR1 promoter methylation in head and neck squamous cell carcinoma. Hum Mol Genet 2011 21(7):1557-1565.

64. Katz J, Onate MD, Pauley KM, Bhattacharyya I, Cha S: Presence of Porphyromonas gingivalis in gingival squamous cell carcinoma. Int J Oral Sci 2011, 3(4):209-215.

65. Hayashi C, Gudino CV, Gibson FC III, Genco CA: Pathogen-induced inflammation at sites distant from oral infection: bacterial persistence and induction of cell-specific innate immune inflammatory pathways. Mol Oral Microbiol 2010, 25(5):305-316.

66. Lerman LS, Fischer SG, Hurley I, Silverstein K, Lumelsky N: Sequencedetermined DNA separations. Annu Rev Biophys Bioeng 1984, 13:399-423.

67. Ercolini D: PCR-DGGE fingerprinting: novel strategies for detection of microbes in food. J Microbiol Methods 2004, 56(3):297-314

68. Rocas IN, Siqueira JF Jr, Aboim MC, Rosado AS: Denaturing gradient gel electrophoresis analysis of bacterial communities associated with failed endodontic treatment. Oral Surg Oral Med Oral Pathol Oral Radiol Endod 2004, 98(6):741-749.

69. Zaura E, Keijser BJ, Huse SM, Crielaard W: Defining the healthy "core microbiome" of oral microbial communities. BMC Microbiol 2009, 9:259.

70. Siqueira JF, Rocas IN: Uncultivated phylotypes and newly named species associated with primary and persistent endodontic infections. J Clin Microbiol 2005, 43(7):3314-3319.

71. Eribe ER, Olsen I: Leptotrichia species in human infections. Anaerobe 2008 14(3):131-137

72. Ruoff KL: Miscellaneous catalase-negative, gram-positive cocci: emerging opportunists. J Clin Microbiol 2002, 40(4):1129-1133.

73. Carlier J-P, K'ouas G, Bonne I, Lozniewski A, Mory F: Oribacterium sinus gen. nov., sp. nov., within the family 'Lachnospiraceae' (phylum Firmicutes). Int J Syst Evol Microbiol 2004, 54(5):1611-1615.

74. Morita E, Narikiyo M, Yokoyama A, Yano A, Kamoi K, Yoshikawa E, Yamaguchi T, Igaki $\mathrm{H}$, Tachimori $Y$, Kato $H$, et al: Predominant presence of Streptococcus anginosus in the saliva of alcoholics. Oral Microbiol Immunol 2005, 20(6):362-365.

75. Gray T: Streptococcus anginosus group: clinical significance of an important group of pathogens. Clin Microbiol News/ 2005, 27(20):155-159.

76. Nakazawa F, Miyakawa H, Fujita M, Kamaguchi A: Significance of asaccharolytic Eubacterium and closely related bacterial species in the human oral cavity. J Expt Clin Med 2011, 3(1):17-21. 
77. Colombo APV, Teles RP, Torres MC, Souto R, Rosalém W, Mendes MCS, Uzeda M: Subgingival microbiota of brazilian subjects with untreated chronic periodontitis. J Periodontol 2002, 73(4):360-369.

78. Paster BJ, Boches SK, Galvin JL, Ericson RE, Lau CN, Levanos VA, Sahasrabudhe A, Dewhirst FE: Bacterial diversity in human subgingival plaque. J Bacterio/ 2001, 183(12):3770-3783.

79. Fitzpatrick SG, Katz J: The association between periodontal disease and cancer: a review of the literature. J Dent 2010, 38(2):83-95.

80. Kumagai K, Sugano N, Takane M, Iwasaki H, Tanaka H, Yoshinuma N, Suzuki K, Ito K: Detection of Streptococcus anginosus from saliva by real-time polymerase chain reaction. Lett Appl Microbiol 2003, 37(5):370-373.

81. van Houte J, Lopman J, Kent R: The final $\mathrm{pH}$ of bacteria comprising the predominant flora on sound and carious human root and enamel surfaces. J Dent Res 1996, 75:1008-1014.

82. van Houte J, Sansone C, Joshipura K, Kent R: Mutans streptococci and non- mutans streptococci acidogenic at low $\mathrm{pH}$, and in vitro acidogenic potential of dental plaque in two different areas of the human dentition. J Dent Res 1991, 70:1503-1507.

83. Beighton D: The complex oral microflora of high-risk individuals and groups and its role in the caries process. Community Dent Oral Epidemiol 2005, 33(4):248-255.

84. Downes J, Wade WG: Peptostreptococcus stomatis sp. nov., isolated from the human oral cavity. Int I Syst Evol Microb 2006, 56(4):751-754.

85. Lunt SJ, Chaudary N, Hill RP: The tumor microenvironment and metastatic disease. Clin Exp Metastasis 2009, 26(1):19-34.

86. Mazzio E, Smith B, Soliman K: Evaluation of endogenous acidic metabolic products associated with carbohydrate metabolism in tumor cells. Cell Biol Toxicol 2010, 26(3):177-188.

87. Collins MD, Hutson RA, Falsen E, Sjoden B, Facklam RR: Description of Gemella sanguinis sp. nov., isolated from human clinical specimens. J Clin Microbiol 1998, 36(10):3090-3093.

88. Willems A, Collins MD: Evidence for the placement of the gram-negative Catonella morbi (Moore and Moore) and Johnsonella ignava (Moore and Moore) within the Clostridium subphylum of the gram-positive bacteria on the basis of $16 \mathrm{~S}$ rRNA sequences. Int I Syst Bacteriol 1995, 45(4):855-857.

89. Michaud DS, Liu Y, Meyer M, Giovannucci E, Joshipura K: Periodontal disease, tooth loss, and cancer risk in male health professionals: a prospective cohort study. Lancet Oncol 2008, 9(6):550-558.

90. Rosenquist K, Wennerberg J, Schildt EB, Bladström A, Göran Hansson B, Andersson $\mathrm{G}$ : Oral status, oral infections and some lifestyle factors as risk factors for oral and oropharyngeal squamous cell carcinoma. A population-based case-control study in southern Sweden. Acta Otolaryngol 2005, 125(12):1327-1.

91. Tezal M, Sullivan MA, Reid ME, Marshall JR, Hyland A, Loree T, Lillis C, Hauck L, Wactawski-Wende J, Scannapieco FA: Chronic periodontitis and the risk of tongue cancer. Arch Otolaryngol Head Neck Surg 2007, 133(5):450-454.

92. Aas JA, Paster BJ, Stokes LN, Olsen I, Dewhirst FE: Defining the normal bacterial flora of the oral cavity. J Clin Microbiol 2005, 43(11):5721-5732

93. Mager DL, Ximenez-Fyvie LA, Haffajee AD, Socransky SS: Distribution of selected bacterial species on intraoral surfaces. J Clin Periodontol 2003, 30(7):644-654.

94. Allavena P, Garlanda C, Borrello MG, Sica A, Mantovani A: Pathways connecting inflammation and cancer. Curr Opin Genet Dev 2008, 18(1):3-10.

95. Kurago Z, Lam-ubol A, Stetsenko A, De La Mater C, Chen Y, Dawson D: Lipopolysaccharide-Squamous Cell Carcinoma-Monocyte interactions induce cancer-supporting factors leading to rapid STAT3 activation. Head Neck Pathol 2008, 2(1):1-12.

96. Berezow AB, Darveau RP: Microbial shift and periodontitis. Periodontol 2011, 55(1):36-47.

doi:10.1186/1471-2180-12-144

Cite this article as: Pushalkar et al.: Comparison of oral microbiota in tumor and non-tumor tissues of patients with oral squamous cell carcinoma. BMC Microbiology 2012 12:144.

\section{Submit your next manuscript to BioMed Central and take full advantage of:}

- Convenient online submission

- Thorough peer review

- No space constraints or color figure charges

- Immediate publication on acceptance

- Inclusion in PubMed, CAS, Scopus and Google Scholar

- Research which is freely available for redistribution 